\title{
Evaluating Nitrogen Use Efficiency (NUE) Indices on the Background of Mineral Status of the Seed Crop at Maturity: a Case Study of Maize
}

\author{
Witold Szczepaniak* \\ Department of Agricultural Chemistry and Environmental Biogeochemistry, Poznan University of Life Sciences, \\ Wojska Polskiego 71F, 60-637 Poznan, Poland
}

Received: 22 September 2015

Accepted: 16 February 2016

\begin{abstract}
The first step in assessing nitrogen fertilizer's impact on the environment relies on its productivity. Several series of indices have been developed to describe nitrogen use efficiency (NUE). Their usability as potential agro-environmental tools depends, among other things, on the degree of responsiveness to crop nutritional status at its maturity. Selected NUE indices were evaluated based on grain yield, the number of kernels per con (NKC), and general crop indicators such as i) total nutrient uptake (TNU), ii) nutrient harvest index (NHI), and iii) unit nutrient uptake (UNU). This concept was validated using original experimental data on maize response to increasing nitrogen rates $\left(0,100,150\right.$, and $\left.200 \mathrm{~kg} \mathrm{ha}^{-1}\right)$ on the background of long-term potassium fertilizing systems, differing in soil $\mathrm{K}$ fertility level (medium, high) and $\mathrm{K}$ fertilizer application $(\mathrm{K} 0, \mathrm{~K}+)$. The most promising indices of diagnostic values to describe both agronomic and environmental impacts of nitrogen fertilizer were the partial factor productivity of nitrogen fertilizer $\left(\mathrm{PFP}_{\mathrm{FN}}\right)$ and apparent nitrogen recovery (NR). The first one, directly describing productivity of the unit of applied nitrogen fertilizer, showed high sensitivity to those nutrients, which significantly defined maize yield. In the studied case it refers to potassium, whose low supply during the critical window resulted in a significant decrease in the number of kernels per cob. Consequently, the reduced capacity of the maize physiological sink during the grain-filling period resulted in the apparent excess of phosphorus and magnesium. This conclusion is corroborated by an N/P ratio of 7.4-10.8:1 and an N/K ratio of 7.4-10.8:1. This was the key reason for limiting productivity of nitrogen fertilizer. The NR index was the slightly poorer indicator of nitrogen fertilizer management, but also responded significantly both to natural and experimentally induced factors that are decisive for production variability. Other frequently used NUE indices did not allow for making both a simple and reliable evaluation of the nitrogen fertilizer productivity under different management systems.
\end{abstract}

Keywords: nitrogen productivity, total nutrient uptake, nutrient harvest index, unit nutrient uptake, maize

*e-mail: witeczek@up.poznan.p 


\section{Introduction}

The sustainability concept as the "road map" of modern agriculture is a big challenge for farmers. The key question is how to increase agricultural production to feed the world's continually growing population without negatively impacting the environment. The primary objective can be achieved by increasing the area of arable soils and/or by increasing yields. The first way is limited, because all fertile soils are already in agricultural use. Hence progress in food production depends principally on yield increase. Nowadays, maize - due to its high-yield potential - is considered a key crop, having a production capacity to cover the growing worldwide demand for grain [1-3].

It is well recognized that any yield increment in maize is possible provided that a significant input of resources, mainly nitrogen, is the key factor responsible for dry matter production $[4,5]$. The key problem of sustainable management of nitrogen in the soil-plant system is low productivity of applied nitrogen fertilizer, defined as nitrogen use efficiency (NUE) [1,6]. This term includes two basic physiological processes $[7,8]$. The first defines processes responsible for nitrogen uptake from the soil. In intensive production, based on fertilizers, it refers to the contribution by the applied $\mathrm{N}$ in total or in the main product, for example grain. The NUE index, based on this assumption, is known as apparent nitrogen recovery $\left(\mathrm{R}_{\mathrm{N}}\right)$. The second index, termed as nitrogen physiological efficiency $\left(\mathrm{PhE}_{\mathrm{N}}\right)$, describes a set of metabolic processes that are responsible for transforming previously accumulated nitrogen into the harvestable part of the crop plant. The product of both indices is known as agronomic nitrogen use efficiency $\left(\mathrm{AE}_{\mathrm{N}}\right)$. The first and the third index are frequently considered as indicators of potential environmental impact of nitrogen fertilizer [1]. Their usefulness results from the fact the only part of the total amount of nitrogen fertilizer $\left(\mathrm{N}_{\mathrm{F}}\right)$ introduced into the soilplant system is taken up by the $\operatorname{crop}\left(\mathrm{N}_{\mathrm{U}}\right)$ :

$$
\mathrm{N}_{\mathrm{F}}=\mathrm{N}_{\mathrm{U}}+\mathrm{N}_{\mathrm{S}}+\mathrm{N}_{\mathrm{L}}
$$

Part of the non-consumed $\mathrm{N}$ by plants undergoes fixation $\left(\mathrm{N}_{\mathrm{s}}\right)$ both by microbes and/or directly to soil particles. This part, termed residual nitrogen, is potentially available to crops, but only in the subsequent cropping season. The part of the applied nitrogen fertilizer marked $\mathrm{N}_{\mathrm{L}}$ is lost from the cropping system, resulting in contamination of water (underground, surface) and the atmosphere [9]. The efficiency of nitrogen fertilizer applied by farmers globally is paltry, ranging from 20 to $40 \%[1,6]$. In turn, the low recovery rate of nitrogen fertilizer creates a big threat to the environment and to human health. Therefore, the key objective of modern agriculture, oriented on sustainability, is to diminish losses of nitrogen fertilizer into the environment by increasing its use by currently grown crops $[10,11]$.

Due to its rapid expansion in temperate regions of the world, including Poland, maize requires much attention by farmers, environmentalists, and scientists. There is a substantial yield gap between the potential of modern varieties and actual yields $[2,12]$. The key physiological principle of the effective in-season management of nitrogen fertilizer in maize is strictly related to its dynamics during the cardinal stages of yield formation [4]. The first peak of $\mathrm{N}$ requirements is revealed at leaf stage 5-7. During this particular stage, the flower initials are established [5]. Therefore, any factor impacting nitrogen uptake increases the probability of the fulfilling crop yield potential. This is the case of zinc and magnesium when they are applied to maize before this stage $[13,14]$.

The second cardinal stage of $\mathrm{N}$ uptake by maize extends from tasselling to the watery stage of kernel development. The rate of nitrogen uptake in this particular stage is driven by balanced uptake of other nutrients, such as potassium, phosphorus, and magnesium [15-20]. In modern staygreen varieties, the amount of nitrogen taken up by maize at the beginning of flowering constitutes around $50 \%$ of its final uptake $[4,5,21]$. The amount of mineral nitrogen taken up by maize during the grain-filling period depends to a great extent, irrespective of nutrient supply, on crop capacity to its utilization [22-24]. The remaining part, termed as residual soil mineral nitrogen (RSMN), creates a potential threat for the environment. The increase of NUE is the first step in decreasing the amount of residual soil nitrogen as the prerequisite for lowering its potential leaching $[25,10]$.

Productivity of nitrogen fertilizer is highly affected by the course of weather during the growing season. Poland, based on climatic criteria, belongs to the continental zone, whose main attributes are frequent drought during the vegetative season with frequently occurring high temperatures [26]. Therefore, crop plants are threatened by abiotic stresses. Potassium supply is a nutritional factor significantly affecting yield of seed crop, especially mild under-water stress, as frequently reported in Central Europe [27]. It is therefore assumed that water shortages can be ameliorated, at least partly, by the adequate management of potassium, as the key nutritional factor improving nitrogen productivity $[17,28]$.

The major objective of this study was to evaluate a set of indices describing nitrogen use efficiency (NUE) based on maize mineral status at maturity. The minor objective of the study was to evaluate the sensitivity of both sets of indicators to the potassium fertilizing systems.

\section{Materials and Methods}

Studies on indices of nitrogen use efficiency as agroenvironmental indicators were validated based on field experiments conducted during the three consecutive growing seasons of 2004, 2005, and 2006 at RGD Brody (Poznan University of Life Sciences Experimental Station; $16^{\circ} 28^{\prime} \mathrm{E}$ and $\left.52^{\circ} 44^{\prime} \mathrm{N}\right)$. The experimental long-term trial was established in 1991 on Albic Luvisol originating from loamy sand underlined by light loam. The field trial arranged as the two-factorial split-block design, replicated 
four times, comprised the following set of factors:

1. Potassium fertilizing system: four treatments,

2. Rates of nitrogen fertilizer of $0,100,150$, and $200 \mathrm{~kg} \mathrm{~N} \mathrm{ha}^{-1}$.

The tested systems of potassium fertilization are the combination of: i) medium $\mathrm{K}$ fertility plot with and without fertilizer potassium application (acronym MK0, $\mathrm{MK}+$, respectively), ii) high soil $\mathrm{K}$ fertility plot with and without fertilizer potassium application $(\mathrm{HK} 0, \mathrm{HK}+)$.

Maize (variety Eurostar, FAO 240) was used as the test plant. All fertilizers were applied in spring, just before sowing. Rates and forms of used nutrients were as follows: i) $\mathrm{P}_{2} \mathrm{O}_{5}-80 \mathrm{~kg} \cdot \mathrm{ha}^{-1}$ as SSP (single superphosphate), ii) $\mathrm{K}_{2} \mathrm{O}-160 \mathrm{~kg} \cdot \mathrm{ha}^{-1}$ as $\mathrm{KCl}$, and iii) nitrogen as ammonium nitrate $(34 \%)$. The first rate of $100 \mathrm{~kg} \mathrm{~N} \mathrm{ha}^{-1}$ was applied before sowing. The remaining $\mathrm{N}$ rates were added in accordance with the experimental schedule at the stage of 3(5) maize leaf. All other agrotechnologies were in accordance with standard practice. The individual plot size was $22.4 \mathrm{~m}^{2}$. At maturity, crops were harvested from the area of $11.2 \mathrm{~m}^{2}$. Total grain yields were adjusted to $14 \%$ moisture content.

Plant samples for yield, biomass, and cob structure determination were taken up from an area of one $\mathrm{m}^{2}$ at $\mathrm{BBCH}$ 89. Nitrogen concentration in plant samples was determined by the standard macro-Kjeldahl procedure. Plant material for mineral element determination was mineralized at $640^{\circ} \mathrm{C}$ and the obtained ash was next dissolved in $33 \% \mathrm{HNO}_{3}$. The phosphorus measurement was conducted using the vanadium-molybdenum method by the Specord $2 \mathrm{XX} / 40$ at $436 \mathrm{~nm}$ wave. Potassium and calcium were determined by flame-photometry and magnesium by flame atomic absorption spectrometry. Results are expressed on a dry matter basis.

The general indicators of maize nutritional status were calculated based on data on nutrient concentration and crop biomass. The index, termed as nutrient total uptake (TNU), was calculated by multiplying each nutrient concentration and the respective biomass. The nutrient harvest index, NHI, defining a percentage of a given nutrient in the main yield, was determined using equation:

$$
\mathrm{NHI}=\left(\mathrm{G}_{\mathrm{Nu}} / \mathrm{TNU}\right) \cdot 100[\%]
$$

The index, termed as unit nutrient accumulation (UNU), was calculated as the ratio of TNU for a given nutrient and the respective yield of grain, as presented below for nitrogen:

$$
\mathrm{UNU}=\mathrm{TNU} / \mathrm{Y}, \mathrm{kg} \text { grain } \mathrm{kg}^{-1} \mathrm{~N}
$$

...where $\mathrm{G}_{\mathrm{Nu}}$ is the amount of a given nutrient in grain $\left(\mathrm{kg} \mathrm{ha}^{-1}\right)$, TNU is the amount of a given nutrient in the whole crop biomass $\left(\mathrm{kg} \mathrm{ha}^{-1}\right)$, and $\mathrm{Y}$ is yield of grain $\left(\mathrm{t} \mathrm{ha}^{-1}\right)$.

Two main sets of indices of nitrogen use efficiency have been developed based on:

1. Yield of grain:

a) Partial factor productivity of nitrogen fertilizer,
$\mathrm{PFP}_{\mathrm{FN}}=\mathrm{Y} / \mathrm{N}_{\mathrm{r}}, \mathrm{kg}_{\text {grain }} \mathrm{kg}^{-1} \mathrm{~N}$

b) Agronomic nitrogen use efficiency, $\mathrm{AE}_{\mathrm{N}}=\left(\mathrm{Y}_{\mathrm{N}}-\mathrm{Y}_{0}\right) /$ $\mathrm{N}_{\mathrm{r}}, \mathrm{kg}$ grain $\mathrm{kg}^{-1} \mathrm{~N}$

c) Physiological nitrogen use efficiency, $\mathrm{PhE}_{\mathrm{N}}=\left(\mathrm{Y}_{\mathrm{N}}-\right.$ $\left.\mathrm{Y}_{0}\right) /\left(\mathrm{NU}_{\mathrm{N}}-\mathrm{NU}_{0}\right), \mathrm{kg}$ grain $\mathrm{kg}^{-1} \mathrm{~N}$

2. Biomass:

a) Total productivity of nitrogen fertilizer, $\mathrm{TP}_{\mathrm{FN}}=\mathrm{B} / \mathrm{N}_{\mathrm{r}}, \mathrm{kg}$ biomass kg${ }^{-1} \mathrm{~N}$

b) Total nitrogen use efficiency, $\mathrm{TE}_{\mathrm{N}}=\left(\mathrm{B}_{\mathrm{N}}-\mathrm{B}_{0}\right) / \mathrm{N}_{\mathrm{r}}$, $\mathrm{kg}$ grain $\mathrm{kg}^{-1} \mathrm{~N}$

c) Apparent $\mathrm{N}$ recovery, $\mathrm{R}_{\mathrm{N}}=\left(\mathrm{NU}_{\mathrm{N}}-\mathrm{NU}_{0}\right) / \mathrm{N}_{\mathrm{r}} \cdot 100, \%$

d) Total physiological nitrogen use efficiency, $\mathrm{TPhE}_{\mathrm{N}}=\left(\mathrm{B}_{\mathrm{N}}-\mathrm{B}_{0}\right) /\left(\mathrm{NU}_{\mathrm{N}}-\mathrm{NU}_{0}\right), \mathrm{kg}$ grain $\mathrm{kg}^{-1} \mathrm{~N}$ ...where $\mathrm{Y}_{\mathrm{N}}$ is yield of grain harvested from the plot with applied nitrogen $\left(\mathrm{kg} \mathrm{ha}^{-1}\right), \mathrm{Y}_{0}$ is yield of grain harvested in control $\left(\mathrm{kg} \mathrm{ha}^{-1}\right), \mathrm{B}_{\mathrm{N}}$ is biomass produced by maize on the plot with applied nitrogen $\left(\mathrm{kg} \mathrm{ha}^{-1}\right), \mathrm{B}_{0}$ is biomass produced by maize in control $\left(\mathrm{kg} \mathrm{ha}^{-1}\right), \mathrm{N}_{\mathrm{r}}$ is nitrogen fertilizer rate $\left(\mathrm{kg} \mathrm{N} \mathrm{ha}^{-1}\right), \mathrm{NU}_{\mathrm{N}}$ is total nutrient uptake in crop biomass in the plot with applied nitrogen $\left(\mathrm{kg} \mathrm{ha}^{-1}\right)$, and $\mathrm{NU}_{0}$ is total nutrient uptake in crop biomass in control $\left(\mathrm{kg} \mathrm{ha}^{-1}\right)$.

The experimentally obtained data were subjected to conventional analysis of variance using the computer program STATISTICA 10. The differences between treatments were evaluated using Tukey's test. Tables and figures present results of the $\mathrm{F}$ test $(* * *, * *, *$ indicate significance at $P<0.1 \%, 1 \%$, and 5\%, respectively). In the second step of NUE indices validation, stepwise regression was applied to define the optimal set of variables. In the computing procedure, a consecutive variable was taken from the multiple linear regressions in the step-by-step manner. The best regression model was chosen based on the highest $F$-value for the entire model and significance of all independent variables.

\section{Results and Discussion}

Three groups of general crop indicators of maize mineral status at maturity were used to validate NUE indices. The first, describing the total nutrient uptake (TNU), informs about the amount of a particular nutrient in harvested crop biomass. The second one, nutrient harvest index (NHI), is a dimensionless indicator of a given element partition in the mature crop, i.e., between the principal product, for example, in cereals, grain and the residual biomass known as straw. The third index termed as the unit nutrient uptake (UNU) defines the amount of a particular nutrient per unit of main product and its amount in the respective amount of vegetative biomass. In the first step of the NUE indices' validation, all these indicators were evaluated by two yield characteristics. The first was the number of kernels per cob (NKC), and the second grain yield (GY).

\section{Growth Conditions and Grain Yield}

The period extending from one week before and three weeks after flowering of maize is termed as the critical window. It is a decisive period for seed set up. Two 
Table 1. Total accumulation of nutrients $\left(\mathrm{g} \mathrm{m}^{-2}\right)$.

\begin{tabular}{|c|c|c|c|c|c|c|}
\hline Main factor & Level of the factor & $\mathrm{N}$ & $\mathrm{P}$ & $\mathrm{K}$ & $\mathrm{Mg}$ & $\mathrm{Ca}$ \\
\hline \multirow[t]{4}{*}{ Years } & 2004 & $20.81^{\mathrm{b}}$ & $1.97^{\mathrm{a}}$ & $13.95^{\mathrm{b}}$ & $1.85^{\mathrm{b}}$ & $3.29^{\mathrm{c}}$ \\
\hline & 2005 & $18.06^{\mathrm{a}}$ & $2.30^{\mathrm{b}}$ & $14.53^{b}$ & $1.21^{\mathrm{a}}$ & $2.56^{\mathrm{a}}$ \\
\hline & 2006 & $21.52^{\mathrm{b}}$ & $2.68^{\mathrm{c}}$ & $10.26^{\mathrm{a}}$ & $2.02^{\mathrm{c}}$ & $3.00^{\mathrm{b}}$ \\
\hline & $\mathrm{F}$ & $35.46^{* * *}$ & $56.01^{* * *}$ & $73.24^{* * *}$ & $113.2^{* * *}$ & $31.27^{* * *}$ \\
\hline \multirow{5}{*}{$\begin{array}{l}\text { Potassium fertilizing } \\
\text { systems }\end{array}$} & MK0 & $19.22^{\mathrm{a}}$ & $2.20^{\mathrm{a}}$ & $11.57^{\mathrm{a}}$ & 1.71 & 2.99 \\
\hline & $\mathrm{MK}+$ & $21.12^{\mathrm{b}}$ & $2.42^{\mathrm{b}}$ & $13.22^{\mathrm{bc}}$ & 1.77 & 3.03 \\
\hline & HK0 & $19.94^{\mathrm{ab}}$ & $2.32^{\mathrm{ab}}$ & $12.67^{\mathrm{ab}}$ & 1.66 & 3.00 \\
\hline & $\mathrm{HK}+$ & $20.26^{\mathrm{ab}}$ & $2.32^{\mathrm{ab}}$ & $14.20^{\mathrm{c}}$ & 1.63 & 2.98 \\
\hline & $\mathrm{F}$ & $4.89^{* *}$ & $2.72^{*}$ & $12.37^{* *}$ & 1.973 & 0.896 \\
\hline \multirow[t]{5}{*}{ Nitrogen rates } & 0 & $15.42^{\mathrm{a}}$ & $2.05^{\mathrm{a}}$ & $11.02^{\mathrm{a}}$ & $1.32^{\mathrm{a}}$ & $2.38^{\mathrm{a}}$ \\
\hline & 100 & $20.08^{\mathrm{b}}$ & $2.31^{\mathrm{b}}$ & $12.41^{b}$ & $1.73^{\mathrm{b}}$ & $2.85^{\mathrm{b}}$ \\
\hline & 150 & $22.39^{c}$ & $2.44^{\mathrm{b}}$ & $14.08^{c}$ & $1.84^{\mathrm{b}}$ & $3.28^{\mathrm{c}}$ \\
\hline & 200 & $22.64^{c}$ & $2.46^{\mathrm{b}}$ & $14.12^{\mathrm{c}}$ & $1.88^{\mathrm{b}}$ & $3.30^{c}$ \\
\hline & $\mathrm{F}$ & $88.58^{* * *}$ & $11.9^{* * *}$ & $22.76^{* * *}$ & $30.74^{* * *}$ & $32.48^{* * * *}$ \\
\hline
\end{tabular}

${ }^{a}$ numbers marked with the same letter are not significantly different; ${ }^{* * *}, * *, *$ : probability levels at $0.001,0.01$, and 0.05 , respectively

processes are responsible for the final number of kernels per cob (NKC) [29]. The first is fertilization of flowers and the second the rate of seed initials natural abortion. The NKC under favorable conditions can reach 500. Any internal and/or external conditions disturbing fertilization of ovules or growth of seed initials leads to its abortion, in turn decreasing the NKC. In rain-fed agriculture, both processes are highly sensitive to water shortages during the critical window [30].

In the studied period, the total sum of water during the period extending from January to the end of September amounted to $413 \mathrm{~mm}$ in 2004, $529 \mathrm{~mm}$ in 2005, and $400 \mathrm{~mm}$ in 2006 (Table 1). Amounts of precipitation during maize vegetation were 229, 361, and $269 \mathrm{~mm}$, respectively. However, decisive for the seed setup was the critical window period, covering the second and third decades of July and the 1 August. In 2004, the total amount of water was $36 \mathrm{~mm}$ and the NKC ranged from 338 in the potassium unfertilized plot (MK0) to 402 in the high-potassium fertile plot with currently added potassium (HK+). In 2005 the amount of rainfall water in this particular period reached $97 \mathrm{~mm}$. The NKC was high, rising under these favorable conditions from 460 in the MK0 to 480 in plants grown in K fertile plots (HK). The worst conditions for seed set up were in 2006. The amount of precipitation during the critical window was $106 \mathrm{~mm}$, but in July only nine $\mathrm{mm}$. This resulted in a drastic drop in NKC. It amounted to 224 in the MK0, rising up in other treatments to 275 . The recorded response of NKC to water and potassium supply in 2004 and 2006 corroborates so far published observations $[17,28]$. The hypothesis concerning the ameliorative impact of an adequate supply of potassium on the formation of yield components by seed crops was proven to be under a mild year as recorded in 2004, but not in a very dry 2006 .

Maize yield was driven by interaction of years and potassium management systems (Fig. 1). In 2004 a specific impact of potassium systems on grain yield was observed. A slightly higher yield was an attribute of both the medium fertile plot with added $\mathrm{K}$ fertilizer $(\mathrm{MK}+)$ and the high fertility plot, but without freshly added $\mathrm{K}$ fertilizer (HK0). The yield gain due to effective supply of potassium compared with the K control (MK0) amounted to 0.9 and $0.4 \mathrm{tha}^{-1}$. The phenomenon observed in $2004 \mathrm{can}$ be explained by maize's ability to use effectively the nonexchangeable potassium resources [16, 31]. This finding

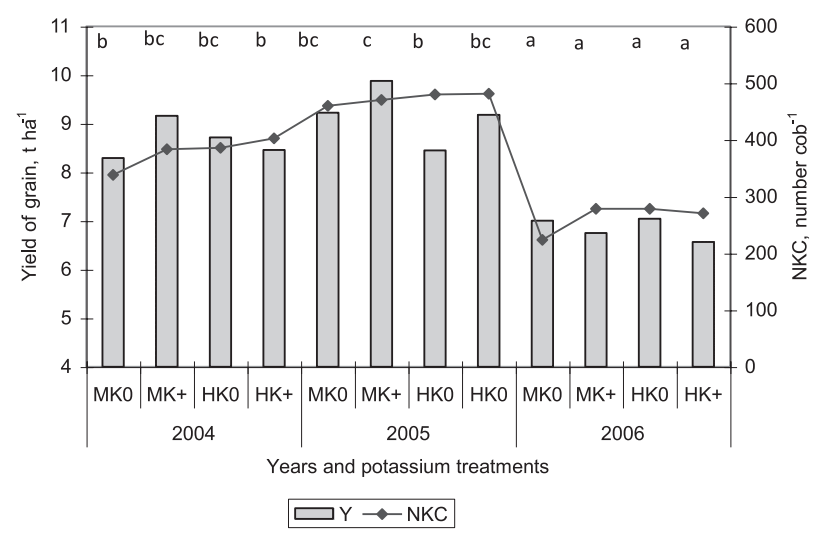

Fig. 1. Effect of potassium treatments on the number of kernels per cob (NKC) and grain yield (GY) in consecutive years of the study.

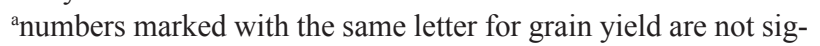
nificantly different. 
is in accordance with Damm, et al. [32], who observed a faster growth rate of maize roots under conditions of semi-drought, providing a fresh application of fertilizer potassium. In the second, 2005, characterized by an ample water supply to growing plants, yields were very high. The highest of $9.9 \mathrm{t} \mathrm{ha}^{-1}$ was again an attribute of $\mathrm{MK}+$ plot. The yield gain due to added $\mathrm{K}$ fertilizer amounted to $0.65 \mathrm{tha}^{-1}$. The lowest yields, irrespective of K management systems, were recorded in 2006, with drought in July. The key reason for the yield (Y) drop was the insufficient size of the physiological sink, i.e., NKC. This conclusion was corroborated by the developed regression model:

$$
\begin{gathered}
\mathrm{Y}=0.011 \mathrm{NKC}+4.248 \text { for } \mathrm{n}=12, \\
\mathrm{R}^{2}=0.78 \text { and } \mathrm{P} \leq 0.001
\end{gathered}
$$

This equation implicitly corroborates the hypothesis on seed density as the key yield variable for grain yield. Therefore, any stress factor, like water shortage, that leads to kernel abortion results in yield drop $[15,21]$.

\section{Total Nutrient Uptake}

The amount of a particular nutrient in the crop biomass at harvest, considered the primary characteristic of maize mineral status, was significantly affected by the course of weather during the growing season. The range of nutrients averaged over experimental treatments in descending order was as follows:

$$
\begin{gathered}
\mathrm{N}(181-215)>\mathrm{K}(103-145)> \\
\mathrm{Ca}(26-33)>\mathrm{P}(20-27)>\mathrm{Mg}(12-20) \mathrm{kg} \mathrm{ha}^{-1}
\end{gathered}
$$

The effect of potassium fertilizing systems on total nutrient uptake (TNU) was significant for nitrogen, phosphorus, and potassium (Table 1). The effect of nitrogen fertilizing rates on total nutrient accumulation was positive - up to $100 \mathrm{~kg} \mathrm{~N} \mathrm{ha}^{-1}$ for phosphorus and magnesium, and to $150 \mathrm{~kg} \mathrm{~N} \mathrm{ha}^{-1}$ for nitrogen and potassium. The effect of potassium systems on nutrients uptake was reported for nitrogen and phosphorus in the $\mathrm{MK}+$ plot. The water stress in 2006, considerably depressed potassium uptake, but not the accumulation of other nutrients. Potassium is considered the primary factor affecting nitrogen uptake during a water shortage $[17,28]$.

The impact of TNU indices on yield performance was complex. The stepwise analysis allowed developing regression models, discriminating the effect of particular nutrients on the NKC and GY. The respective equations are:

$$
\begin{gathered}
\mathrm{NKC}=901.1-84.55 \mathrm{TPU}-197.4 \mathrm{TMgU} \\
\text { for } \mathrm{R}^{2}=0.94
\end{gathered}
$$

$$
\begin{gathered}
\mathrm{GY}=6.777-4.349 \mathrm{TMgU}+2.986 \mathrm{TCaU} \\
\text { for } \mathrm{R}^{2}=0.83
\end{gathered}
$$

These two relationships clearly corroborate the hypothesis that excess phosphorus (TPU) and magnesium $(\mathrm{TMgU})$ in maize at its physiological maturity can be considered indicators of growth disturbance [16]. These two equations evidently inform us that amounts of accumulated phosphorus and magnesium were in excess with respect to NKC and GY. At the same time, the content of calcium became a factor limiting yield. The excess of calcium in seeds can be considered an indicator of water stress.

The effect of $\mathrm{K}$ fertilizing systems on nitrogen, phosphorus, and potassium whole uptake was significantly modified by the course of weather during each of the growing seasons. However, the significant relationship with grain yield has been found only for TKU and GY:

$$
\begin{gathered}
\mathrm{GY}=-0.552 \mathrm{KA}^{2}+183.3 \mathrm{TKU}-5957 \\
\text { for } \mathrm{n}=12, \mathrm{R}^{2}=0.78
\end{gathered}
$$

This equation implicitly indicates that potassium content reached the saturation level in the maize canopy. For the calculated TKU optimum of $166 \mathrm{~kg} \mathrm{~K} \mathrm{ha}^{-1}$, the maximum yield was $9,259 \mathrm{~kg} \mathrm{ha}^{-1}$. The theoretical yield was very close to the yield harvested on the plot with the medium $\mathrm{K}$ soil fertility level and applied potassium fertilizer $(\mathrm{MK}+)$. This fact indirectly indicates the presence of other factors, limiting potassium uptake from plots rich in potassium (HK).

\section{Nutrient Harvest Index}

The studied harvest indices, except for calcium, were significantly affected by the course of weather (Table 2). The most striking impact of the year-to-year variability was reported for nitrogen and phosphorus. Their values declined in the order: $2005>2004>2006$. The potassium fertilizing system affected nitrogen, phosphorus, and potassium partition the most in the $\mathrm{HK}+$ plot, increasing its content in vegetative biomass in expense of grain. These indices only in 2005 were at the level reported for the high productive systems [21]. A positive impact of nitrogen fertilizing rates on nutrient harvest indices reached the maximum at $\mathrm{N}$ rate of $100 \mathrm{~kg} \mathrm{ha}^{-1}$, decreasing thereafter. The magnesium harvest index showed the same year-toyear variability trend as found for nitrogen. The impact of the potassium management system on $\mathrm{MgHI}$ reached an elevated level in the K-rich plot but without current application of fertilizer (HK0). The effect of nitrogen increasing rates on its values was as a rule negative.

The yield-forming effect of studied indices on grain yield was highly complex, as results from developed regression models. It has been found that yield of maize significantly depended on PHI:

$$
\begin{gathered}
\mathrm{GY}=-0.27+12.63 \mathrm{PHI} \\
\text { for } \mathrm{R}^{2}=0.86
\end{gathered}
$$


Table 2. Statistical evaluation of nutrient harvest indices.

\begin{tabular}{|c|c|c|c|c|c|c|}
\hline Main factor & Level of the factor & $\mathrm{N}$ & $\mathrm{P}$ & K & $\mathrm{Mg}$ & $\mathrm{Ca}$ \\
\hline \multirow[t]{4}{*}{ Years } & 2004 & $0.64^{\mathrm{b}}$ & $0.71^{\mathrm{b}}$ & $0.18^{\mathrm{a}}$ & $0.55^{\mathrm{b}}$ & 0.05 \\
\hline & 2005 & $0.69^{c}$ & $0.74^{\mathrm{b}}$ & $0.25^{\mathrm{b}}$ & $0.44^{\mathrm{a}}$ & 0.05 \\
\hline & 2006 & $0.53^{\mathrm{a}}$ & $0.56^{\mathrm{a}}$ & $0.28^{c}$ & $0.41^{\mathrm{a}}$ & 0.06 \\
\hline & $\mathrm{F}$ & $202.8^{* * *}$ & $118.4^{* * *}$ & $94.35^{* * *}$ & $53.57^{* * *}$ & 2.622 \\
\hline \multirow{5}{*}{$\begin{array}{l}\text { Potassium fertilizing } \\
\text { systems }\end{array}$} & MK0 & $0.63^{\mathrm{b}}$ & $0.68^{\mathrm{b}}$ & $0.26^{\mathrm{b}}$ & $0.46^{\mathrm{ab}}$ & 0.05 \\
\hline & $\mathrm{MK}+$ & $0.62^{\mathrm{ab}}$ & $0.68^{\mathrm{b}}$ & $0.24^{b}$ & $0.45^{\mathrm{a}}$ & 0.05 \\
\hline & $\mathrm{HK} 0$ & $0.62^{\mathrm{ab}}$ & $0.68^{\mathrm{b}}$ & $0.23^{\mathrm{ab}}$ & $0.50^{\mathrm{b}}$ & 0.06 \\
\hline & $\mathrm{HK}+$ & $0.60^{\mathrm{a}}$ & $0.64^{\mathrm{a}}$ & $0.22^{\mathrm{a}}$ & $0.46^{\mathrm{ab}}$ & 0.05 \\
\hline & $\mathrm{F}$ & $3.75^{*}$ & $3.36^{*}$ & $6.617^{* * *}$ & $3.984^{* *}$ & 1.982 \\
\hline \multirow[t]{5}{*}{ Nitrogen rates } & 0 & $0.64^{\mathrm{b}}$ & $0.64^{\mathrm{a}}$ & $0.24^{\mathrm{ab}}$ & $0.50^{\mathrm{b}}$ & $0.06^{\mathrm{b}}$ \\
\hline & 100 & $0.62^{\mathrm{ab}}$ & $0.69^{\mathrm{b}}$ & $0.26^{\mathrm{b}}$ & $0.48^{\mathrm{ab}}$ & $0.05^{\mathrm{a}}$ \\
\hline & 150 & $0.61^{\mathrm{a}}$ & $0.67^{\mathrm{ab}}$ & $0.23^{\mathrm{a}}$ & $0.44^{\mathrm{a}}$ & $0.05^{\mathrm{a}}$ \\
\hline & 200 & $0.61^{\mathrm{a}}$ & $0.67^{\mathrm{ab}}$ & $0.24^{\mathrm{ab}}$ & $0.45^{\mathrm{a}}$ & $0.05^{\mathrm{a}}$ \\
\hline & F & $7.60 * * *$ & $4.12^{* *}$ & $2.912^{*}$ & $6.202^{* * *}$ & $4.739^{* *}$ \\
\hline
\end{tabular}

${ }^{a}$ numbers marked with the same letter are not significantly different; ${ }^{* * *}, * *, *$ : probability levels at $0.001,0.01$, and 0.05 , respectively

The key yield-forming factor, $\mathrm{NKC}$, was also significantly dependent on PHI:

$$
\begin{gathered}
\mathrm{NKC}=-321.4+1029 \mathrm{PHI} \\
\text { for } \mathrm{R}^{2}=0.86
\end{gathered}
$$

These sets of equations implicitly indicate the phosphorus mineral status of maize at maturity as a factor reflecting disturbance in yield component performance. It can be assumed that too low PHI was the result of the insufficient size of the physiological sink for phosphorus, i.e., NKC. Therefore, it can be concluded that the reduced number of kernels was the key reason for the excess of non-productive phosphorus in maize at harvest.

\section{Indices of Unit Nutrient Uptake}

The indices of the unit nutrient uptake (UNU), except for potassium, were driven by the course of weather during a particular season (Table 3 ). With respect to this factor the obtained ranges, presented in descending order, are as follows:

$$
\begin{aligned}
& \mathrm{N}(19-31)>\mathrm{K}(15-16)>\mathrm{Ca}(2.8-4.4) \\
& \quad>\mathrm{P}(2.3-4.0)>\mathrm{Mg}(1.3-2.9) \mathrm{kg} \mathrm{t}^{-1}
\end{aligned}
$$

These ranges are, except for magnesium, higher than those published recently by Bender et al. [1]. The main reason for the differences is the level of grain yield. In the studied case it reached eight $\mathrm{tha}^{-1}$, but in the cited paper on average it was $12 \mathrm{t} \mathrm{ha}^{-1}$. The lowest values were recorded in 2005, the year with the highest GY, whereas 2006 saw the lowest yield. These differences indirectly indicate the potential productivity of most nutrients, but especially of nitrogen, phosphorus, and magnesium provided an ample supply of water. The impact of potassium fertilizing systems on UNU was found for nitrogen, phosphorus, and potassium. All these indices responded significantly to current $\mathrm{K}$ fertilizer application, irrespective of soil $\mathrm{K}$ fertility level. The highest value was reported for the K-rich plot currently fertilized with potassium.

The UNU indices for nitrogen, phosphorus, magnesium, and calcium were negatively correlated with yield and NKC. The best regression models are as follows:

$$
\begin{gathered}
\mathrm{GY}=11.98-0.58 \mathrm{UPU}-0.97 \mathrm{UMgU} \\
\text { for } \mathrm{R}^{2}=0.88 \\
\mathrm{NKC}=798.7-17.08 \mathrm{UMgU} \\
\text { for } \mathrm{R}^{2}=0.95
\end{gathered}
$$

These two equations implicitly indicate an excess of phosphorus and magnesium. In fact, they can be considered indicators of maize growth disturbance during grain yield formation due to insufficient size of the physiological sink, i.e., NKC.

In agronomic practice, three indices such as UNU, UPU, and UKU require special attention due to their prevailing impact on plant growth during the vegetative season. The optimum N/P and N/K ratios in maize at maturity for maximum yield of grain should reach 5:1 and $1: 1$, respectively [4]. In the studied case, the N/P ratio was in the range 7.4-10.8:1. The range indicates on the 
Table 3. Unit accumulation of nutrients $\left(\mathrm{kg} \mathrm{t}^{-1}\right.$ grain + respective biomass of vegetative part).

\begin{tabular}{|c|c|c|c|c|c|c|}
\hline Main factor & Level of the factor & $\mathrm{N}$ & $\mathrm{P}$ & $\mathrm{K}$ & $\mathrm{Mg}$ & $\mathrm{Ca}$ \\
\hline \multirow[t]{4}{*}{ Years } & 2004 & $24.06^{\mathrm{b}}$ & $2.29^{\mathrm{a}}$ & 16.21 & $2.14^{\mathrm{b}}$ & $3.84^{\mathrm{b}}$ \\
\hline & 2005 & $19.06^{\mathrm{a}}$ & $2.51^{\mathrm{b}}$ & 16.02 & $1.33^{\mathrm{a}}$ & $2.81^{\mathrm{a}}$ \\
\hline & 2006 & $31.41^{\mathrm{c}}$ & $3.97^{\mathrm{c}}$ & 15.20 & $2.92^{\mathrm{c}}$ & $4.39^{c}$ \\
\hline & $\mathrm{F}$ & $339.4^{* * *}$ & $224.1^{* * *}$ & 2.168 & $334.1^{* * *}$ & $83.43^{* * *}$ \\
\hline \multirow{5}{*}{$\begin{array}{l}\text { Potassium fertilizing } \\
\text { systems }\end{array}$} & MK0 & $23.90^{\mathrm{a}}$ & $2.75^{\mathrm{a}}$ & $14.16^{\mathrm{a}}$ & 2.14 & 3.71 \\
\hline & $\mathrm{MK}+$ & $25.33^{\mathrm{b}}$ & $2.94^{\mathrm{ab}}$ & $15.38^{\mathrm{ab}}$ & 2.18 & 3.64 \\
\hline & HK0 & $25.05^{\mathrm{ab}}$ & $2.98^{\mathrm{ab}}$ & $15.85^{\mathrm{b}}$ & 2.08 & 3.64 \\
\hline & $\mathrm{HK}+$ & $25.84^{\mathrm{b}}$ & $3.03^{\mathrm{b}}$ & $17.84^{c}$ & 2.11 & 3.71 \\
\hline & $\mathrm{F}$ & $4.89^{* *}$ & $2.956^{*}$ & $13.23^{* * *}$ & 0.704 & 0.132 \\
\hline \multirow[t]{5}{*}{ Nitrogen rates } & 0 & $22.20^{\mathrm{a}}$ & 3.03 & 15.72 & $1.92^{\mathrm{a}}$ & $3.42^{\mathrm{a}}$ \\
\hline & 100 & $24.96^{\mathrm{b}}$ & 2.87 & 15.16 & $2.17^{\mathrm{b}}$ & $3.55^{\mathrm{ab}}$ \\
\hline & 150 & $26.42^{c}$ & 2.88 & 16.21 & $2.10^{\mathrm{b}}$ & $3.85^{\mathrm{b}}$ \\
\hline & 200 & $26.52^{c}$ & 2.93 & 16.15 & $2.23^{\mathrm{b}}$ & $3.89^{\mathrm{b}}$ \\
\hline & $\mathrm{F}$ & $29.34^{* * *}$ & 1.125 & 1.334 & $8.44^{* * *}$ & $5.2^{* *}$ \\
\hline
\end{tabular}

${ }^{a}$ numbers marked with the same letter are not significantly different; ${ }^{* * *},{ }^{* *}, *$ : probability levels at $0.001,0.01$, and 0.05 , respectively

imbalance of nitrogen and phosphorus unit uptake due to insufficient accumulation of the second nutrient in grain.

The above-presented controversy has been explained by studying the variability of unit potassium uptake index. Its values were the result of interaction of both potassium fertilizing systems and nitrogen increasing rates. As presented in Fig. 2, plants grown on medium $\mathrm{K}$ fertile soil without freshly applied potassium (MK0) increased the UKU in accordance to the progressing $\mathrm{N}$ rates. A much steeper increase, however, was noted for the rich $\mathrm{K}$ soil - also without K fertilizer application. Quite different trends took place in K sub-plots, currently supplied with $\mathrm{K}$ fertilizer. In the medium fertility $\mathrm{K}$ soil, any response to increasing $\mathrm{N}$ rates was noted. In the fertile $\mathrm{K}$ soil even a decreased trend was observed.

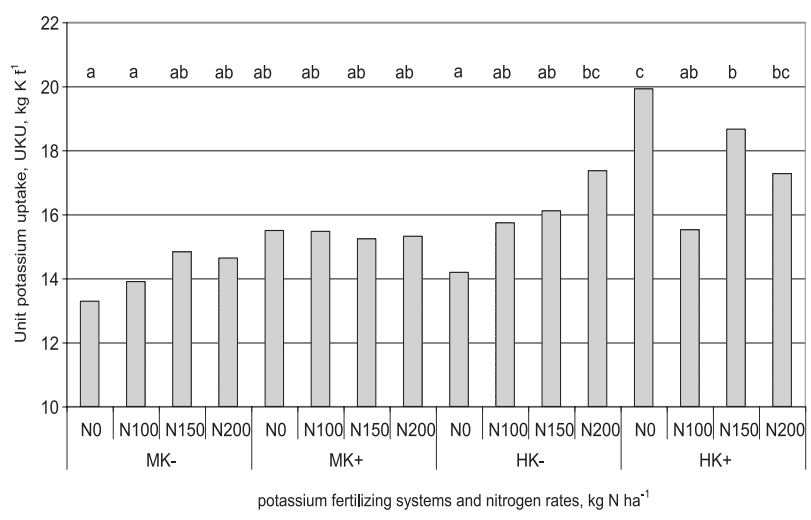

Fig. 2. Effect of potassium fertilizing systems and increasing nitrogen rates on the unit potassium uptake index. anumbers marked with the same letter are not significantly different.
Potassium treatments without freshly applied potassium indirectly underline the importance of $\mathrm{K}$ soil reserves as a source of $\mathrm{K}$ for growing plants, especially for $\mathrm{K}$ to reach the soil. This finding corroborates the concept that cereal crops are able to use efficiently soil $\mathrm{K}$ resources when provided with a high supply of this nutrient during the growing season [17-19, 28, 31]. The simple index, such as the $\mathrm{N}: \mathrm{K}$ ratio, varied from 1.25 to 2.17:1. The highest yield of $9.65 \mathrm{t} \mathrm{ha}^{-1}$ was obtained in two treatments. The first one represents the $\mathrm{MK}+$ plot and the second the HK0. As shown in Fig. 3, the increasing $\mathrm{N}: \mathrm{K}$ ratio resulted in a decrease in the number of kernels. Therefore, the controversy concerning on the one hand a deficiency of phosphorus and on the other hand its excess at maize at maturity can be explained only by the reduced capacity of the maize physiological sink, i.e. the NKC. As a consequence, maize requirements for some nutrients like phosphorus and magnesium significantly decreased,

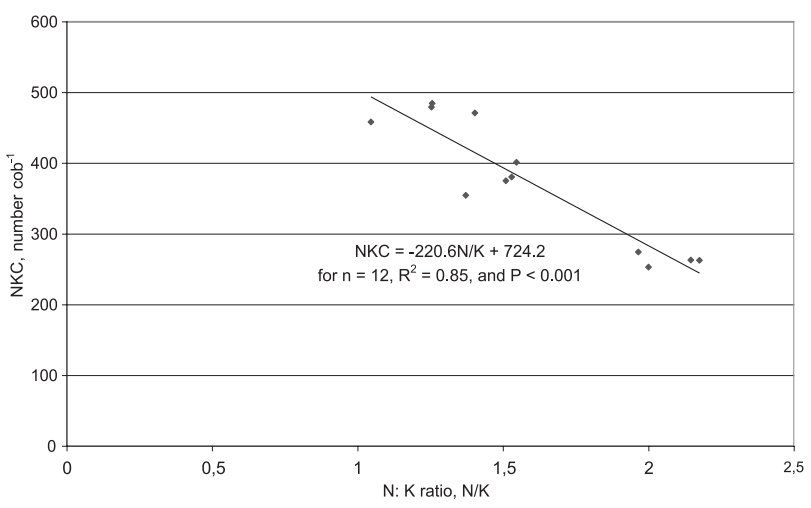

Fig. 3. Number of kernels per cob as a function of the N/K ratio. 
Table 4. Statistical evaluation of indices of nutrient use efficiency.

\begin{tabular}{|c|c|c|c|c|c|c|c|c|}
\hline Main factor & $\begin{array}{c}\text { Level } \\
\text { of the factor }\end{array}$ & $\begin{array}{l}\mathrm{PFP}_{\mathrm{FN}} \\
\mathrm{kg} \mathrm{kg}^{-1}\end{array}$ & $\begin{array}{c}\mathrm{AE}_{\mathrm{N}} \\
\mathrm{kg} \mathrm{kg}^{-1}\end{array}$ & $\begin{array}{l}\mathrm{PhE}_{\mathrm{N}} \\
\mathrm{kg} \mathrm{kg}^{-1}\end{array}$ & $\begin{array}{l}\mathrm{TFP}_{\mathrm{FN}} \\
\mathrm{kg} \mathrm{kg}^{-1}\end{array}$ & $\begin{array}{c}\mathrm{BE}_{\mathrm{N}} \\
\mathrm{kg} \mathrm{kg}^{-1}\end{array}$ & $\begin{array}{l}\mathrm{R}_{\mathrm{N}} \\
\%\end{array}$ & $\begin{array}{l}\mathrm{TPhE}_{\mathrm{N}} \\
\mathrm{kg} \mathrm{kg}^{-1}\end{array}$ \\
\hline \multirow{4}{*}{ Years } & 2004 & $63.82^{\mathrm{b}}$ & 7.85 & -7.36 & $121.28^{\mathrm{b}}$ & $12.74^{\mathrm{a}}$ & $33.63^{\mathrm{a}}$ & 27.01 \\
\hline & 2005 & $68.46^{c}$ & 9.59 & 47.63 & $117.34^{\mathrm{b}}$ & $14.06^{\mathrm{a}}$ & $34.30^{\mathrm{a}}$ & 51.34 \\
\hline & 2006 & $52.21^{\mathrm{a}}$ & 11.94 & 18.27 & $107.15^{\mathrm{a}}$ & $27.32^{\mathrm{b}}$ & $61.18^{\mathrm{b}}$ & 44.85 \\
\hline & $\mathrm{F}$ & $73.36^{* * *}$ & 1.962 & 0.876 & $23.12^{* * *}$ & $10.53^{* * *}$ & $20.09^{* * *}$ & 0.067 \\
\hline \multirow{9}{*}{$\begin{array}{l}\text { Potassium } \\
\text { fertilizing } \\
\text { systems }\end{array}$} & MK0 & 60.93 & 9.23 & 24.12 & $113.58^{\mathrm{ab}}$ & 18.21 & 44.36 & 24.79 \\
\hline & $\mathrm{MK}+$ & 63.68 & 7.51 & 20.77 & $119.88^{\mathrm{b}}$ & 14.59 & 38.31 & 66.78 \\
\hline & HK0 & 60.08 & 9.00 & 33.33 & $112.65^{\mathrm{a}}$ & 20.79 & 43.38 & 82.31 \\
\hline & $\mathrm{HK}+$ & 61.30 & 13.43 & -0.16 & $114.92^{\mathrm{ab}}$ & 18.58 & 46.09 & -9.62 \\
\hline & $\mathrm{F}$ & 1.87 & 2.256 & 0.174 & $3.37^{*}$ & 0.7996 & 0.683 & 0.549 \\
\hline & 100 & $82.49^{c}$ & 10.90 & 63.56 & $152.39^{c}$ & 17.79 & 46.60 & 124.22 \\
\hline & 150 & $57.98^{\mathrm{b}}$ & 10.26 & -13.12 & $110.30^{\mathrm{b}}$ & 20.57 & 46.45 & -23.16 \\
\hline & 200 & $44.03^{\mathrm{a}}$ & 8.23 & 8.10 & $83.07^{\mathrm{a}}$ & 15.77 & 36.06 & 22.14 \\
\hline & $\mathrm{F}$ & $397.1^{* * *}$ & 0.902 & 1.812 & $530.4^{* * *}$ & 0.939 & 2.970 & 2.409 \\
\hline
\end{tabular}

${ }^{a}$ numbers marked with the same letter are not significantly different; ${ }^{* * *}, * *, *$ : probability levels at $0.001,0.01$, and 0.05 , respectively

in turn negatively affecting the productivity of nitrogen fertilizer.

\section{Indices of Nitrogen Use Efficiency}

The most promising agro-environmental NUE index, taking into account the key objective of this paper, seems to be $\mathrm{PFP}_{\mathrm{FN}}$ followed by $\mathrm{TFP}_{\mathrm{FN}}$ (Table 4). The advantage of this index over others results from its sensitivity both to the course of weather and experimental factors. This index, alone among others, showed a significant response to rates of nitrogen fertilizer. As expected, its values decreased in the opposite way to increasing rates of nitrogen fertilizer. The FP $_{\mathrm{FN}}$ was the highest, averaged over other factors, in treatment with $100 \mathrm{~kg} \mathrm{~N} \mathrm{ha}^{-1}$. The $1 \mathrm{~kg} \mathrm{~N}$ fertilizer resulted in 82 of grain. This value is high, but below the maximum in Polish conditions, ranging from 96 to $103 \mathrm{~kg}_{\text {grain }} \mathrm{kg}^{-1}$ $\mathrm{N}$ [27]. The main reason of the only good value of $\mathrm{PFP}_{\mathrm{FN}}$ was the low NKC. As a result, maize was unable to take additional amounts of nitrogen from soil during the grainfilling period. The respective values of $\mathrm{TFP}_{\mathrm{FN}}$ were almost double compared to $\mathrm{PFP}_{\mathrm{FN}}$ ones. The $\mathrm{TFP}_{\mathrm{FN}}$, as alone, showed a significant response to the potassium fertilizing system. The freshly added potassium resulted in the TFP index increased. Therefore, in years with water stress, the difference in unit productivity of nitrogen fertilizer is, as a rule, much lower for biomass compared to grain. It simply means low efficiency of nitrogen remobilization during the grain-filling period due to insufficient capacity of the physiological sink [20, 24, 30].

The agronomic nitrogen efficiency index, $\mathrm{AE}_{\mathrm{N}}$, was a weak indicator of nitrogen productivity in the highyielding maize system. Much higher sensitivity, but only to the course of weather, was reported for the $\mathrm{BE}_{\mathrm{N}}$. Its values were twice as high in the dry 2006 compared to other years. The same trend of response was noted for nitrogen recovery $\left(R_{N}\right)$. Its value in 2006 was slightly above $60 \%$, whereas in the two other years it did not exceed $35 \%$. All other NUE indices did not show any response to both the course of weather and experimental factors (Table 4). Both sets of NUE indices were evaluated using three groups of predictors: yield and NKC, TNU, and UNU.

The analysis of the $\mathrm{PFP}_{\mathrm{FN}}$ predictive potential has been fully corroborated for grain yield, which is not surprising when considering the calculation procedure. As presented below, the best regression model has been achieved, introducing into the model also the $\mathrm{AE}_{\mathrm{N}}$ :

$$
\begin{gathered}
\mathrm{GY}=0.08+0.139 \mathrm{PFP}_{\mathrm{FN}}-0.043 \mathrm{AE}_{\mathrm{N}} \\
\text { for } \mathrm{R}^{2}=0.99
\end{gathered}
$$

The predictive dominance of $\mathrm{PFP}_{\mathrm{FN}}$ has been corroborated by the regression model developed for NKC:

$$
\begin{gathered}
\mathrm{NKC}=-329.4+11.15 \mathrm{PFP}_{\mathrm{FN}}+0.748 \mathrm{PhE}_{\mathrm{N}} \\
\text { for } \mathrm{R}^{2}=0.99
\end{gathered}
$$

These two equations implicitly indicate reduced grain yield and NKC due to insufficient productivity of nitrogen fertilizer. The reason is rooted in the imbalanced nutritional status of maize in stages of NKC performance [29, 30]. It has been well documented that water stress during the period extending from the tasselling to the watery stages of kernel growth results in a reduction in NKC [17]. It can be concluded that a shortage of potassium during this 
period results in the NKC decrease, in turn negatively affecting nitrogen fertilizer productivity.

The advanced procedure of NUE indices evaluation relies on the degree of their sensitivity to indicators of maize mineral status at harvest. In the studied case, the highest prognostic impact of each NUE index was an attribute of magnesium and calcium. The predictive strength of these two nutrients (presented by the $\mathrm{R}^{2}$ coefficient) decreased in the order:

$$
\mathrm{NR}(0.85) \geq \operatorname{PFP}_{\mathrm{FN}}(0.83)>\operatorname{PhE}(0.54)>\mathrm{AE}(0.37)
$$

The respective equations for two best NUE indices are:

$$
\begin{gathered}
\mathrm{R}_{\mathrm{N}}=103+64.25 \mathrm{TMgU}-57.16 \mathrm{TCaU} \\
\text { for } \mathrm{R}^{2}=0.85
\end{gathered}
$$

$$
\begin{gathered}
\mathrm{PFP}_{\mathrm{FN}}=57.99-28.14 \mathrm{TMgU}+17.33 \mathrm{TCaU} \\
\text { for } \mathrm{R}^{2}=0.83 .
\end{gathered}
$$

Effective management of nitrogen in maize tissues, as presented by these two equations, depends on relationships between magnesium and calcium. The analysis of the $R_{N}$ equation implicitly corroborates the conclusion chosen by Potarzycki [22]. This author clearly showed that magnesium can significantly increase nitrogen recovery, provided a relatively low rate of nitrogen fertilizer. This conclusion is fully corroborated by equation No. 12. The sign of the magnesium factor indirectly informs the nonproductive excess of this nutrient in maize tissues at the stage of maturity. The importance of magnesium as the $\mathrm{PFP}_{\mathrm{FN}}$ predictor has been reinforced, taking into account the UNU index as the denominator. The best predictive model has been obtained based on magnesium and phosphorus unit uptake indices:

$$
\begin{gathered}
\mathrm{PFP}_{\mathrm{FN}}=85.5-3.33 \mathrm{UPU}-7.16 \mathrm{UMgU} \\
\text { for } \mathrm{R}^{2}=0.92
\end{gathered}
$$

The second set of indices, based on biomass produced by maize, showed slightly weaker predictability of TFP ${ }_{\mathrm{FN}}$ by both TNU and UNU as denominators. At the same time, the best model operated on quite different sets of nutrients compared to the $\mathrm{PFP}_{\mathrm{FN}}$ index:

$$
\begin{gathered}
\mathrm{TFP}_{\mathrm{FN}}=55.95+5.66 \mathrm{~K}+8.87 \mathrm{Ca} \\
\text { for } \mathrm{R}^{2}=0.66
\end{gathered}
$$

This model indirectly indicates a reduced accumulation of nitrogen in vegetative biomass at maize maturity due to shortages of potassium and calcium, meaning that productivity of nitrogen fertilizer was therefore related, to some extent, to crop biomass instead to GY. The main reason was too low performance of the cob, leading to an excess of phosphorus and magnesium. This conclusion is supported by the negative signs of the unit productivity factor in the equation presented below:

$$
\begin{gathered}
\mathrm{TFP}_{\mathrm{FN}}=136-7.07 \mathrm{UPU} \\
\text { for } \mathrm{R}^{2}=0.53
\end{gathered}
$$

The conducted divagation also showed that the classical index, i.e., agronomic efficiency, was only useful for describing the impact of nitrogen fertilizer on biomass productivity. The best model for this index can be developed to include magnesium and calcium as predictors:

$$
\begin{gathered}
\mathrm{BE}=57.26+36.61 \mathrm{TMgU}-34.28 \mathrm{TCaU} \\
\text { for } \mathrm{R}^{2}=0.80
\end{gathered}
$$

As in the case of $\mathrm{TFP}_{\mathrm{FN}}$, these two secondary nutrients became decisive for nitrogen productivity.

\section{Conclusion}

The conducted study implicitly showed that indices describing nitrogen use efficiency presented different responses to growth conditions impacted by natural and agronomic factors. The best indicator of nitrogen fertilizer productivity was the partial factor productivity of nitrogen fertilizer $\left(\mathrm{PFP}_{\mathrm{FN}}\right)$. This index can be used as the predictor of both NKC and GY. The obtained regression models implicitly indicate that productivity of applied nitrogen fertilizer is most governed by the number of kernels per cob. The reduced size of the physiological sink resulted in decreased requirements of the growing cob for nitrogen, phosphorus, and magnesium during the grain-filling period. Therefore, nitrogen fertilizer reached maximum unit productivity of $82 \mathrm{~kg}$ in the treatment with $100 \mathrm{~kg} \mathrm{~N} \mathrm{ha}^{-1}$. The $\mathrm{PFP}_{\mathrm{FN}}$ index was highly sensitive to any growth disturbance, therefore it can be considered a useful tool for efficient management of nitrogen fertilizer, taking into account both i) its productivity and ii) potential threat of residual mineral nitrogen to the environment. The conducted study implicitly showed an excess of magnesium and phosphorus in maize tissues at physiological maturity. The apparent excess of both nutrients was a result of growth disturbance during the critical window due to insufficient supply of potassium to maize plants. Deficiency in potassium supply resulted in lowered NKC.

\section{References}

1. CASSMAN K.G., DOBERMANN A., WALTERS D.T. Agroecosystems, nitrogen use-efficiency, and nitrogen management. Ambio 31 (2), 132, 2002.

2. CIAMPITTI I.A., VYN T.J. Understanding global and 
historical nutrient use efficiencies for closing maize yield gaps. Agron. J. 106, 2107, 2014.

3. EDGERTON M.D. Increasing crop productivity to meet global needs for feed, food, and fuel. Plant Physiol. 149, 7, 2009.

4. GRZEBISZ W., WROŃSKA M., DIATTA J.B., SZCZEPANIAK W. Effect of zinc application at early stages of maize growth on the patterns of nutrients and dry matter accumulation by canopy. Part II. Nitrogen uptake and dry matter accumulation patterns. J. Elem. 13 (1), 29, 2008.

5. SUBEDI K.D., MA B.L. Nitrogen uptake and partitioning in stay-green leafy maize hybrids. Crop Science, 45, 740, 2005.

6. ROBERTS T.L. Improving nutrient use efficiency. Turk J Agric. F. 32, 177, 2008.

7. HIREL B., LU GOUIS J., GALLAIS A. The challenge of improving nitrogen use efficiency in crop plants: towards a more central role for genetic variability and quantitative genetic within integrated approaches. J. Exp. Bot. 58 (9), 2369, 2007

8. HIREL B., TÉTU T., LEA P.J., DUBOIS F. Improving nitrogen use efficiency in crops for sustainable agriculture. Sustainability 3, 1452, 2011.

9. EICKHOUT B., BOUWMAN A.F., ZEIJTS. H. The role of nitrogen in world food production and environmental sustainability. Agric. Ecosys. Environ. 116, 4, 2006.

10. HAENE K.D'., SALOMEZ J., DE NEVE S., DE WAELE J., HOFMAN G. Environmental performance of nitrogen fertilizer limits imposed by the EU Nitrates Directive. Agric. Ecosys. Environ., 192, 67, 2014.

11. STARK CH.H., RICHARDS K.G. The continuing challenge of agricultural nitrogen loss to the environment in the context of global change and advancing research. Dynamic Soil, Dynamic Plant 2 (2), 41, 2008.

12. FAOSTAT. 2014. Available online; accessed 2014-10-14.

13. GRZEBISZ W., WROŃSKA M., DIATTA J.B., DULLIN P. Effect of zinc application at early stages of maize growth on the patterns of nutrients and dry matter accumulation by canopy. Part I. Zinc uptake patterns and its redistribution among maize organs. J. Elem. 13 (1), 29, 2008.

14. POTARZYCKI J., GRZEBISZ W. Effect of zinc foliar application on grain yield of maize and its yielding components. Plant Soil Environ., 55 (12), 519, 2009.

15. GRZEBISZ W., PRZYGOCKA-CYNA K., SZCZEPANIAK W., DIATTA J., POTARZYCKI J. Magnesium as a nutritional tool of nitrogen management - plant production and environment. J. Elem. 15 (4), 771, 2010.

16. GRZEBISZ W. Crop response to magnesium fertilization as affected by nitrogen supply. Plant Soil 368, 23, 2013.

17. GRZEBISZ W., GRANSEE A., SZCZEPANIAK W., DIATTA J.B. The effects of potassium fertilization on water useefficiency in crop plants. J. Plant Nutr. Soil Sci. 176, 355, 2013.

18. SZCZEPANIAK W., BARŁÓG P., ŁUKOWIAK R., PRZYGOCKA-CYNA K. Effect of balanced nitrogen fertilization in four-year crop rotation on plant productivity.
J. Central Europ. Agric. 14 (1), 64, 2013.

19. SZCZEPANIAK W., GRZEBISZ W., POTARZYCKI J. An assessment of the effect of potassium fertilizing systems on maize nutritional status in critical stages of growth by plant analysis. J. Elem. 19 (2), 533, 2014.

20. SZULC P. Effects of soil supplementation with urea and magnesium on nitrogen uptake, and utilization by two different forms of maize (Zea mays L.) differing in senescence rates. Pol. J. Environ. Stud. 22 (1), 239, 2013.

21. BENDER R.R., HAEGELE J.W., RUFFO M.L., BELOW F.E. Nutrient uptake, partitioning, and remobilization in modern, transgenic insect-protected maize hybrids. Agron. J. 105, 161, 2013.

22. POTARZYCKI J. Effect of magnesium or zinc supplementation at the background of nitrogen rate on nitrogen management by maize canopy cultivated in monoculture. Plant Soil Environ. 57 (1), 19, 2011.

23. SZULC P. Difference in the accumulation and redistribution of dry matter and $\mathrm{N}_{\min }$ content in the cultivation of two different maize (Zea mays L.) cultivars for grain. Pol. J. Environ. 21 (4), 1039, 2012.

24. UHART S.A., ANDRADE F.H. Nitrogen and carbon accumulation and remobilization during grain filling in maize under different source/sink ratio. Crop Sci. 35, 183, 1995.

25. CHERRY K.A., SHEPHERD M., WITHERS P.J.A., MOONEY S.J. Assessing the effectiveness of actions to mitigate nutrient loss from agriculture: A review of methods. Sci. Tot. Environ., 406, 1, 2008.

26. JOGMANN R., BUNCE R., METZGER R. Objectives and applications of a statistical environmental stratification of Europe. Landscape Ecology 21, 409, 2006.

27. GRZEBISZ W., DIATTA J.B. Constraints and Solutions to Maintain Soil Productivity: A Case Study from Central Europe. In: Soil Fertility Improvement and Integrated Nutrient Management - A Global Perspective. Ed.: Dr. Joann Whalen, $159,2012$.

28. HECKMAN J.R., KAMPRATH J. Potassium accumulation and corn yield related to potassium fertilizer rate and placement. Soil Sci. Soc. Am. J. 73, 141, 1992.

29. OTEGUI M., BONHOMMER R. Grain yield components in maize. I. Ear growth and kernel set. Field Crops Res., 56, 247, 1998

30. OTEGUI M.E., ANDRADE F.H., SUERO E.E. Growth, water use, and kernel abortion of maize subjected to drought at silking. Field Crops Res., 40, 87, 1995.

31. GRZEBISZ W., OERTLI J.J. Evaluation of universal extractants for determining plant available potassium in intensively cultivated soils. Comm. Plant Soil Anal. 24 (11-12), $1295,1993$.

32. DAMM S., HOFMANN B., GRANSEE A., CHRISTEN O. Zur wirkung von Kalium auf ausgewählte bodenphysikalishe Eigenschaften and den Wurzeltiegang landwirtschatlicher Kulturpflanzen. Arch. Agronomy Soil Sci. 59 (1), 1, 2013 